\title{
The Preventive Approach of Biocompounactives (3): A Review in Recent Advances in Cereals and Some Animal-Based Foods
}

\author{
Abdelkarim Guaâdaoui ${ }^{1, ~ *, ~ F a t m a ~ B o u h t i t ~}{ }^{2}$, Mounir Cherfi ${ }^{3}$, Abdellah Hamal ${ }^{1}$ \\ ${ }^{1}$ Department of Biology, Laboratory of Genetics \& Biotechnology (LGB), Faculty of Science - Oujda (FSO), University Mohammed Premier \\ (UMP) Oujda, Morocco \\ ${ }^{2}$ Department biological analysis, Laboratory for Analysis \& Quality Control (LACQ), University Mohammed Premier (UMP) Oujda, \\ Morocco \\ ${ }^{3}$ Medical Analysis Laboratory, Provincial Medical Center of Taourirt, Health Provincial Delegation of Taourirt, Ministry of Health, Morocco
}

\section{Email address:}

abdelkarim119@gmail.com (A. Guaâdaoui)

\section{To cite this article:}

Abdelkarim Guaâdaoui, Fatma Bouhtit, Mounir Cherfi, Abdellah Hamal. The Preventive Approach of Biocompounactives (3): A Review in Recent Advances in Cereals and Some Animal-Based Foods. International Journal of Nutrition and Food Sciences.

Vol. 4, No. 3, 2015, pp. 295-309. doi: 10.11648/j.jinfs.20150403.17

\begin{abstract}
Biocompounactives are compounds which have the capability and the ability to interact with one or more component(s) of the living tissue by presenting a wide range of probable effects. They contain chemicals that are found in small quantities in plants and certain foods (such as fruits, vegetables, nuts, oils and whole grains); and they have actions in the body that can promote good health. All scientific studies confirm that a varied and balanced diet is a factor in protection against cancer, cardiovascular disease (CVD), diabetes, osteoporosis, obesity and high cholesterol. The philosophy that food can be a health promoting beyond its nutritional value is gaining acceptance in the public arena and among the scientific community as mounting research links diet/food components to disease prevention and treatment. In this work, we complete the discussion of the preventive approach of biocompounactives, and opportunities that present bioactivity of cereals and some animal-based foods phytochemicals to prevent many chronic diseases. As well, we finish discussing some challenges related to the evaluation of biological activity by some studies presenting important limitations that must be considered before using data types in the interpretation and extrapolation of phytochemicals bioactivities to Humans.
\end{abstract}

Keywords: Biocompounactives, Bioactive Compound, Phytochemicals, Cereals, Animal-Based Foods, Functional Foods, Healthy Diet, Nutraceuticals

\section{Introduction}

Biocompounactives are compounds which have the capability and the ability to interact with one or more component(s) of the living tissue by presenting a wide range of probable effects. These compounds are experiencing a growing interest in wide range of applications: geo-medicine, plant science, modern pharmacology, agrochemicals, cosmetics, food industry, nano-bio-science... etc. This is a very promising area in full development, which has resulted in research works more and more numerous, designed to diversify the resources of bioactive compounds and improve their salvage pathways or synthesis [1-4].

The importance attached to benefits of food on health has never been so high before [5]. Indeed, over the past two decades, there has been a growing interest in the potential benefits of natural compounds on human health [6], and if we except the genetic, ecological, physiological and botanical studies on food; research on the bioactive potential has experienced a veritable boom during the first decade of the twenty-first century, and took an accelerated rates over the beginning of the second decade, in a way that the research carried out during the past five years (2010-2014) on the majority of foods are equal or superior to the work done during all the previous decade (2000-2009) [3-4].

Noting that prevention is a more effective strategy than is treatment of chronic diseases [7], the philosophy that food can be health promoting beyond its nutritional value is gaining acceptance within the public arena and among the scientific community as mounting research links diet/food 
components to disease prevention and treatment $[5,8]$.

Interest in food composition has expanded beyond the nutrients to include bioactive compounds consumed in the traditional foods, which may help to prevent many chronic diseases that can coexist with malnutrition and undernutrition [9]. Recent trends in the functional food market suggest that products with multiple health benefits become more and more popular [10] and dietary bioactive compounds have become another quality indication [11].

In this work, we complete the discussion of preventive approach of biocompounactives (part 3), and opportunities that present bioactivity of cereals and some animal-based foods phytochemicals to prevent many chronic diseases. As well, we finish discussing of some challenges that face the good investment of biocompounactives.

\section{Food Biocompounactives Opportunities}

The concept of a healthy diet is considered an aspect of good and healthy practices. The observations in social behavior and archaeological discoveries lead researchers to notice that the longevity and healthy life, away from the high incidence of myocardial infarction and cancer, are caused by good habits of feeding [12].

Biocompounactives are members of a large class of organic molecules that are widely distributed in the plant kingdom and, as such, are an integral part of the daily diet of humans [13]. They are non-essential natural ingredients in, or derived from, plant, animal or marine sources, which have the ability to modulate biochemical, physiological and metabolic processes in the human body, while exerting beneficial effects beyond basic nutritional functions [14-16].

Until 2013, it was estimated that more than 8000 phytochemicals have been identified in foods [17]. All these bioactive food components are mostly found in whole grains, fruits and vegetables [18, 19], but a large percentage still remain unknown and need to be identified before we can fully understand the health benefits of phytochemicals in whole foods [18].

The phytochemicals may be classified into carotenoids, phenolic compounds, alkaloids, nitrogen compounds and organosulfur compounds. But the most studied of these biocompounactives are phenolics and carotenoids [20].

Recent investigations show that food biomolecules that contribute to human health can be found particularly in glycosylated, esterified, thiolated or hydroxy forms. These bioactive compounds display their health benefits in metabolic activity associated with several diseases [19].

So the important role that biocompounactives can have in health is related to the intake of these compounds, which, in turn, strongly linked to the high consumption of fruits, vegetables and unrefined grains [21].

Table 1 and 2 constitutes, respectively, a review on major biocompounactives and bioactivities studied for cereals and some animal-based foods that present enormous opportunities for human health.

Table 1. Bioactivity of dietary biocompounactives (Cereals).

\begin{tabular}{|c|c|c|c|}
\hline Cereals & Bioactivities studied & Biocompounactives & References \\
\hline $\begin{array}{l}\text { Barley } \\
\text { Hordeum sp. } \\
\text { (Poaceae) }\end{array}$ & $\begin{array}{l}\text { Inhibit metastasis of colon cancer in vivo } \\
\text { Antiproliferative activity } \\
\text { Inhibit oxidative DNA damage } \\
\text { Reduce diabetes risk } \\
\text { Neuroprotective Effects \& Immunomodulatory } \\
\text { Protecting human brain cells } \\
\text { Cholesterol-lowering effect } \\
\text { Reduce the risk of developing diabetes type } 2\end{array}$ & $\begin{array}{l}\text { Flavanols } \\
\text { Tocols (tocotrienols) } \\
\text { Soluble dietary fiber ( } \beta \text {-glucans \& } \\
\text { arabinoxylans) } \\
\text { Phytosterols } \\
\text { Alkylresorcinols } \\
\text { Lunasin }\end{array}$ & {$[22-47]$} \\
\hline $\begin{array}{l}\text { Corn / Maize } \\
\text { Zea mays } \\
\text { (Poaceae) }\end{array}$ & $\begin{array}{l}\text { Induce apoptosis of liver tumors } \\
\text { Protection against colon cancer } \\
\text { Antimutagenic activity } \\
\text { Protection against DNA damage in certain blood cells } \\
\text { Lower risk of macular degeneration and cataracts } \\
\text { Reduction of blood cholesterol }\end{array}$ & $\begin{array}{l}\text { Carotenoids (Lutein \& Zeaxanthin) } \\
\text { Flavonoids (cyaniding, pelargonidin) } \\
\gamma \text {-tocopherol } \\
\text { Ferulic acid } \\
\text { Phytosterols }\end{array}$ & [48-67] \\
\hline Oat & Normalize intestinal transit & Polyphenols & \\
\hline $\begin{array}{l}\text { Rice } \\
\text { Oryza sp. } \\
\text { (Poaceae) }\end{array}$ & $\begin{array}{l}\text { Induce apoptosis of breast cancer cells and several cell tumors } \\
\text { in humans } \\
\text { Prevent breast and colon cancer in humans } \\
\text { Reduce the incidence of oral and colorectal cancers } \\
\text { Inhibit cancer cell invasion \& antimutagenic activity } \\
\text { Antitumor properties in vitro and in animals } \\
\text { Control diabetes type } 2 \\
\text { Lower blood pressure } \\
\text { Neuroprotective, anti-inflammatory, anti-atherosclerosis \& } \\
\text { hypocholesterolemic effects } \\
\text { Prevention of gastric ulcers in animals } \\
\text { Treat mild to moderate diarrhea }\end{array}$ & $\begin{array}{l}\text { Flavonoids : Anthocyanins (cyanidins, } \\
\text { malvidin, peonidin \& pelargonidin) } \\
\text { Alkaloids (oryzadine) } \\
\alpha \text {-Tocopherol, } \alpha \text { - and } \beta \text {-tocotrienol } \\
\text { Ferulic acid \& coumaric acid } \\
\text { Oryzanols / Tricin / Lectins } \\
\text { Soluble fiber }\end{array}$ & $\begin{array}{l}{[30,} \\
75-113]\end{array}$ \\
\hline
\end{tabular}




\begin{tabular}{|c|c|c|c|}
\hline Cereals & Bioactivities studied & Biocompounactives & References \\
\hline $\begin{array}{l}\text { Rye } \\
\text { Secale cereale L. } \\
\text { (Poaceae) }\end{array}$ & $\begin{array}{l}\text { Preventing breast, skin and colon } \\
\text { Reduce the risk of cardiovascular disease in men } \\
\text { Reduce the risk of heart attack and stroke } \\
\text { Control diabetes type } 2 \\
\text { Prevent oxidation of LDL cholesterol }\end{array}$ & $\begin{array}{l}\text { Phenolic acids } \\
\text { Flavonoids (isoflavonoids) } \\
\text { Carotenoids (lutein \& } \beta \text {-cryptoxanthin) } \\
\text { Tocopherols } \\
\text { Lignans enterolactone } \\
\text { Alk(en)ylrésorcinoles } \\
\text { Soluble fiber ( } \beta \text {-glucans \& } \\
\text { arabinoxylans) } \\
\text { Lunasin }\end{array}$ & [114-139] \\
\hline $\begin{array}{l}\text { Wheat } \\
\text { Triticum sp. } \\
\text { (Poaceae) }\end{array}$ & $\begin{array}{l}\text { Potential antioxidant \& anti-carcinogenic } \\
\text { Inhibit human LDL } \\
\text { Protection against cardiovascular disease, diabetes \& obesity } \\
\text { Maintain proper bowel function }\end{array}$ & $\begin{array}{l}\text { Alkylresorcinols } \\
\text { insoluble fibers } \\
\text { Phytosterols \& Polycasanols }\end{array}$ & $\begin{array}{l}{[23, \quad 24,} \\
114, \\
140-155]\end{array}$ \\
\hline
\end{tabular}

It remains to be noted that the major health role of cereals biocompounactives is linked to a number of factors like other foods. These phytochemicals are mainly found in whole grain and unrefined cereals $[21,156]$ with a different distribution among species, and among parts or tissues of the same plant.

Generally, the content of phytochemicals in foods can be influenced by variety, environment and conditions of growth, maturity stages and harvesting factors [157-160], but little information is available on the influence of cultivation factors or genotype [161], while the impact of harvesting techniques and storage phytochemicals began to be explored in relatively recently [162]. The most studies on the application of food phytochemicals are limited to the examination of their bioactive efficiency [163].

For tocols (e.g.), tocopherols are ubiquitous in all plants and in almost all the green parts of the plant, while tocotrienols are present only in a range of independent groups of plants, and are found almost exclusively in seeds and fruits [164-168] and especially in the fraction of the bran and germ of cereals [169-171], which suggests different functions for tocopherols and tocotrienols in plants, and consequently, different probable bioactivities.

Table 2. Bioactivity of dietary biocompounactives (Animal-based foods).

\begin{tabular}{|c|c|c|c|}
\hline Animal-Based Foods & Bioactivities studied & Biocompounactives & References \\
\hline Egg & $\begin{array}{l}\text { Lower breast cancer risk in perimenopausal women } \\
\text { Build and restore human somatic cells } \\
\text { Prevent macular degeneration related to age } \\
\text { Improve cognitive function } \\
\text { Enhance the immune activity of leukocytes } \\
\text { Activities: antibacterial, antiviral, anti-hypertensive \& } \\
\text { anti-inflammatory }\end{array}$ & $\begin{array}{l}\text { Carotenoids (lutein \& zeaxanthin) } \\
\text { Choline } \\
\text { Ovotransferrin }\end{array}$ & [185-199] \\
\hline Honey & $\begin{array}{l}\text { Anti-proliferative and apoptotic effects } \\
\text { Protection against breast cancer } \\
\text { Solve problems: cardiovascular, glycemic \& gastrointestinal } \\
\text { Inhibit about } 60 \text { species of bacteria } \\
\text { Activities: antiviral, antifungal \& anti-inflammatory }\end{array}$ & $\begin{array}{l}\text { Flavonoids (apigenin, Pinocembrin, } \\
\text { kaempferol, quercétrine, hesperidin, } \\
\text { rutin \& pinostrobine) } \\
\text { Phenolic acids } \\
\text { Tocopherols } \\
\text { Vitamin C } \\
\text { Fibers }\end{array}$ & $\begin{array}{l}{[40,} \\
200-221]\end{array}$ \\
\hline Milk & $\begin{array}{l}\text { Reduce cardiovascular risk } \\
\text { Immunomodulator } \\
\text { Influence nerve networks } \\
\text { Antitumor properties } \\
\text { Anti-inflammatory, Anti-hypertensive \& Antimicrobial } \\
\text { activities }\end{array}$ & $\begin{array}{l}\text { Lactoferrin } \\
\alpha \text {-lactalbumin \& } \alpha \text {-casein } \\
\beta \text {-lactoglobulin } \\
\beta \text {-carotene } \\
\text { Sphingomyelin }\end{array}$ & {$[222-242]$} \\
\hline $\begin{array}{l}\text { Fish } \\
\text { Shellfish }\end{array}$ & $\begin{array}{l}\text { Reduce the risk of Alzheimer's disease } \\
\text { Good immune, circulatory and hormonal functions } \\
\text { Reduce the incidence of arthritis } \\
\text { Activities: antimicrobial, anti-inflammatory \& anti-cancer }\end{array}$ & $\begin{array}{l}\text { Carotenoids (Astaxanthin) } \\
\text { Omega-3 fatty acids: Eicosapentaenoic } \\
\text { acid (EPA) \& Docosahexaenoic acid } \\
\text { (DHA) } \\
\text { Sterols } \\
\text { Complete proteins }\end{array}$ & {$[243-265]$} \\
\hline
\end{tabular}

Another example is that of lignans, which are present in a long range of plants of different families (more than 55 families) $[172,173]$, and in which the total content of lignans varies between cereal species, as well as in same species based on genetic differences and environmental conditions [174]. Rye has a high content of plant lignans among cereals [128, 175, 176]. These biocompounactives have beneficial biological effects $[177,178]$. They have been suggested to induce a wide range of biological effects such as antioxidant, antitumor, antiviral, antibacterial, insecticidal, fungistatic, estrogenic and anti-estrogenic and protect against coronary heart disease [128, 173, 179-181], diabetes [182, 183] and recently an activity against HIV-1 replication in vitro [184]. 


\section{Challenges of the Preventive Approach of Biocompounactives}

Biocompounactives contain chemicals that are found in small quantities in plants and certain foods (such as fruits, vegetables, nuts, oils and whole grains), they have actions in the body that can promote good health [156].

The dose or the amount of food needed to trigger a clinically apparent reaction generally varies between individuals and even in the same individual over time. It also depends on metabolic differences, the concomitant use of drugs, the freshness of food and their preparation [266].

It is true that many phytochemicals such as polyphenols, carotenoids and organosulfur and nitrogen compounds, are thought to be involved in the prevention and treatment of many diseases, including some cancers, cardiovascular diseases, diabetes, degenerative diseases, inflammation, infections, psychotic diseases, ulcers, macular degeneration, ... etc. [267-269]. But, how manifest this mutual interaction between the different biocompounactives and biological systems? and what are the main factors that can affect the physicochemical properties of bioactive compounds in biological systems?

The diversity and complexity of biocompounactives, alone, make the study of all these compounds and understanding their mechanisms of action a very difficult mission. While many critics emerge to highlight, and draw attention to, some details relating to the study of bioactive compounds [4].

The key question is whether a purified phytochemical has the same health benefits as a whole food or a mixture of food where the phytochemical is present. Liu RH (2003) proposes that cumulative and synergistic effects of phytochemicals are responsible for their powerful antioxidant and anticancer activities, and the benefit of a diet is attributed to the complex mixture of phytochemicals found in whole foods [7].

Besides that most studies are conducted with isolated bioactive components, and in addition to take into consideration the possible synergistic effect produced by various bioactive compounds; one must keep in mind that most of the studies are performed in vitro or in vivo in cell lines or biological models, which means that the concentration used is higher than is actually present in the sources of these compounds [270, 271].

So, the major problem for evaluating the biological activity is that these studies present many challenges in the interpretation and extrapolation to humans [4]. Indeed, there are important limitations that must be considered before using data types to support activities of some phytochemicals that "promote health" and interpreting an experiment to prove the effectiveness of a product [270]. These limits include observational and epidemiological studies, and research through the use of cell lines and animal models [4, 270].

\subsection{Observational and Epidemiological Studies}

There are two main types of observational and epidemiological studies: retrospective case-control studies and prospective cohort studies [272-274]. Both types of studies depend on food assessment through, for example, food frequency questionnaires that depend on accurate recall of the diet, which is a challenge in itself. Epidemiological and observational studies suffer from two major problems [270]:

- First, they can provide a relative estimate, as opposed to absolute risk, which can give a misleading impression of health benefits.

- Second, the choice of the control group is complex and difficult, especially as diets are often highly correlated with other lifestyles, attributes, and socioeconomic status. Other confounding factors may influence and complexing results obtained, leading to difficulties in the interpretation of epidemiological studies.

If we take the example cited of lignans; several epidemiological studies have been conducted on associations between concentrations of enterolignans in biological fluids (blood, urine, semen, prostatic fluid), and chronic disease risk $[179,275,276]$. High concentrations of serum enterolactones were associated with a reduced risk of some cancers (breast, ovarian, endometrial, thyroid, prostate, glioma, stomach) and cardiovascular diseases [277-282]. But also several studies found no association or totally gave conflicting results, pointing out, for example, the increase in breast cancer risk with high consumption of secoisolariciresinol and matairesinol [277]. This situation has sparked debate on the role of enterolactones [283].

In contrast, and further epidemiological and observational studies used to determine priorities for public health through scientific methods by pursuing epidemiological transitions and their propagation; each study method present, beside its drawbacks, many advantages which these studies appear effective. The practical value of produce quick results, or study rare outcomes with minimal funding may outweigh the limitations. In addition, there is a permanent development of scientific formulas to improve the efficiency of epidemiological studies, and find new study designs as alternatives less affected by methodological limitations [273, 284-286].

Thus, to provide convincing evidence of the promotional activity of certain chemicals, epidemiological data are often supplemented by findings from experimental studies on cellular and animal models. However, these studies present many challenges in the interpretation and extrapolation to humans [270].

\subsection{Cell Cultures}

Recall that the compounds in the systemic circulation, to which the cells are exposed, are different from those obtained directly from plant and wherein cellular models are frequently exposed in vitro [4]; there are also many practical issues, such as maintaining the conditions and modeling appropriate environment in vitro exposure of bioactive compounds, including those that are lipophilic.

The characteristics of the cell culture technique can also affect the representativeness of the cells response as is the situation in vivo. This is because the cells in culture are not 
maintained under hypoxic conditions and are cultured in the absence of blood circulation of origin, which supports the growth but also major circulating factors such as molecules signaling and hormones. In addition, the intrinsic characteristics of the cells culture can also be problematic in the understanding of the bioactivity. These cells generally exhibit significant changes in physiological and biological properties, such as loss of contact inhibition, and alterations in biochemical functions related to cell cycle checkpoints (e.g. the ability to proliferate indefinitely). Further, a homogeneous type of cell culture is very distant from the in vivo situation, where the original tissue exists in the presence of several other types of neighboring cells and cooperates with them through paracrine signaling [270].

But from another point of view, the cellular models offer an attractive and ethics alternative of animal experimentation for the initial efficacy and mechanistic studies [287-290]:

- They can provide an indication of the biological activity of the phytochemical in question, which can be used to design experiments on animals with the smallest number of animals needed to test hypotheses about the bioactivity.

- The main advantage of using in vitro cell models is practical convenience, such as ease of cultivation, their relatively low cost, moderate performance capabilities, and the existence of a wide selection of cell lines which can be used for different experiments. Moreover, it is relatively easy to modify gene expression to test specific hypotheses about the mechanisms of action of phytochemicals. These are particularly relevant experience for the initial studies on the understanding of disease prevention mechanisms by plant products.

- Culture of homogeneous cell lines isolated from different tissues offers the simplicity and the ability to observe the effects of dietary factors in well-defined and well-controlled environments. This allows better reproducibility of responses within an experiment and in replication between experiments.

Taking again the example of tocols, the study of breast cancer proliferation conducted on cell lines showed high inhibitory activity of tocotrienols in comparison with the tocopherols, whose $\gamma$ - and $\delta$-tocotrienol exert highest inhibitor effects. These results were attributed to preferential absorption of tocotrienols by these cells [2, 291, 292].

One method to avoid problems caused by the absence of a representative microenvironment is to make the cultivation of whole tissues ex vivo by organ/tissue culture. Culturing member maintains the structural and functional characteristics of the biological tissue of interest in vivo, which overcomes the single homogeneous cell culture limitations. However, the tissues show a very short life and are therefore not suitable for longer experiments. The availability of the tissue is also a problem that prevents their use in a medium for analysis of biological effectiveness high throughput. Nevertheless, they can be useful for understanding the biochemical processes in response to plant secondary metabolites [270].

\subsection{Animal Models}

Although animal models in prevention studies are chosen because they have similar characteristics to the illness of the survey; the main limitation is that they never have identical morphological, physiological or biochemical characteristics. In addition, differences in the development of the immune system, activation and response to the challenge between rodents and humans will inevitably affect the translation of the replies to humans. For example, the mouse model of colon cancer APCmin, widely used in cancer prevention studies, differs of Human that tumors are frequently found in the small intestine, which is rare in humans, as opposed to the colon itself. Another important limitation of studies in animal models, particularly relevant to the nutritional research, is the difference between human and rodents in the absorption and metabolism of phytochemicals, because of the difference in the speed of the bloodstream proportionally to the organs and important differences in the quantity and characteristics of the substrate of some CYP (Cytochrome P450). For example, after ingestion, small animals have faster gastric emptying, which affects absorption (10min in rodents against $1 \mathrm{~h}$ in the fasting state in humans), and therefore makes the identification of human equivalent dose from a study on animal models a challenge [270].

In contrast, a wide variety of animal models is used to attempt to recapitulate human disease. Indeed, these models have several advantages, which the principal are [293-297]:

- The high degree of orthology between models and humans. For example, the proportion of orthologous genes between mouse and a single identifiable ortholog in the human genome is about $80 \%$, which makes the mouse an ideal model for studying environmental and genetic manipulation rarely feasible in humans.

- The small size and the short life cycle of some models make them loans at a rapid breeding, and, therefore, the possibility of numerous studies in a relatively short period. Preclinical experiments on animal models can thus be performed in relatively short periods, allowing the chronic study of the response of a disease to dietary manipulation and provides invaluable pharmacological, toxicological and biological information that may predict the clinical efficacy of biocompounactives.

- Genetic homogeneity between the models and the lack of influence of variable environmental factors during the experiments also facilitate studies. In addition, it is possible to perform a complete analysis of disease response by proteomic, transcriptomic and metabolomic analysis, crucially on preand post-mortem at a time. This analyzes made models a precious tool in deciphering the molecular mechanisms involved in the response to phytochemicals.

Polyacetylenes are examples of bioactive metabolites that were previously considered undesirable in plant foods due to their toxicity, but thanks to recent studies conducted both in cell lines and in animal models; these biocompounactives have showed important biological activities, such as antibacterial, antifungal, antiallergenic, anticancer, anti-inflammatory and reduces platelet aggregation. These effects represent pharmacologically useful properties by which polyacetylenes can be used to develop antibiotics in addition to their positive effects on human health [2]. 


\section{Conclusion}

All scientific studies confirm that a varied and balanced diet, with minimal physical activity, is factor of protection against cancer, cardiovascular disease, osteoporosis, diabetes, obesity and high cholesterol. True that these diseases do not depend exclusively on food, they are also influenced by genetic factors, but if we cannot choose our ancestors, we can choose our food and organize our lifestyle [298]!

In the first part of this review, we have presented opportunities that contain some most common vegetables and legumes, with discussion of challenges relating to (i) radical reversal dietary habits and how to provide science to the public, (ii) methods of food processing that may affect the content, activity and bioavailability of biocompounactives in foods, and (iii) allergic reactions of some food-borne phytochemicals that are responsible for a variety of symptoms and disorders in human body [3].

In the second part, we focused on studies that have been conducted on biocompounactives of common fruits, and opportunities that present bioactivity of these phytochemicals to prevent many chronic diseases. As well, emphasis was placed on some challenges that face the good investment of biocompounactives, especially bioavailability and bioefficacy; with discussion of some improvement approaches for these factors, like (i) molecular modeling, (ii) nanotechnologies and (iii) biocatalysts [4].

In this last part, we completed the discussion of preventive approach of biocompounactives and opportunities that present bioactivity of cereals and some animal-based foods phytochemicals to prevent many diseases; and we finished discussing some challenges related to the evaluation of biological activity by (i) observational and epidemiological studies, (ii) cell cultures and (iii) animal models. These studies present important limitations that must be considered before using data types in the interpretation and extrapolation of phytochemicals bioactivities to humans.

Despite challenges described above, different studies have very important benefits. But in all cases, significant efforts are needed to increase the number of clinical studies which are still limited, and, therefore, provide irrefutable evidence of the benefits of bioactive compounds in humans [299].

Experimental studies in humans are an important link between the epidemiological studies and studies in cell culture and animal model systems. They are based on intermediate parameters related to the risk of disease using biological markers that also contribute to providing an overview of mechanisms of action of bioactive constituents in humans. At the same time, these studies are, in turn, limited by the sensitivity and specificity of these biomarkers, access to biological samples, and the logistics of conducting human studies [300].

\section{Acknowledgements}

Abdelkarim G. thanks Professors A. Bouyanzer and A. Mtiri for directions and observations they provided during the preparation of this research.

\section{References}

[1] Abdelkarim $\mathrm{G}$ et al.; What is a bioactive compound? A combined definition for a preliminary consensus. International Journal of Nutrition and Food Sciences, 2014, 3(3): 174-179.

[2] Abdelkarim G et al.; Betalains, Polyacetylenes and Tocols as Biocompounactives: A Concise Review for Enriching the Bioactivity Concept. International Journal of Nutrition and Food Sciences, 2014, 3(4): 230-237.

[3] Abdelkarim $\mathrm{G}$ et al.; The Preventive Approach of Biocompounactives (1): A Review in Recent Advances in Common Vegetables and Legumes. International Journal of Nutrition and Food Sciences. 2015, 4(1): 89-102.

[4] Abdelkarim $G$ et al.; The Preventive Approach of Biocompounactives (2): A Review in Recent Advances in Common Fruits. International Journal of Nutrition and Food Sciences. 2015, 4(2): 189-207.

[5] Bonaccio $\mathrm{M}$ et al.; The Mediterranean diet: The reasons for a success. Thrombosis Research, 2012, 129: 401-404.

[6] Teratanavat R and Hooker NH ; Consumer Valuations and Preference Heterogeneity for a Novel Functional Food. Journal of Food Science, 2006, 71(7): S533-S541.

[7] Liu RH; Health benefits of fruits and vegetables are from additive and synergistic combination of phytochemicals. The American Journal of Clinical Nutrition, 2003, 78(3S): 517S-520S.

[8] Abby B and Cynthia AT; Position of the American Dietetic Association: phytochemicals and functional foods. Journal of the American Dietetic Association, 1995, 95(4): 493-496.

[9] Biesalski HK et al. ; Bioactive compounds: Definition and assessment of activity. Nutrition, 2009, 25(11-12) : 1202-1205.

[10] Day L et al.; Incorporation of functional ingredients into foods. Trends in Food Science and Technology, 2009, 20(9): 388-395.

[11] Park YS et al. ; Analytical determination of bioactive compounds as an indication of fruit quality. Journal of AOAC International, 2012, 95(6): 1725-1732.

[12] Schauss AG ; Emerging Knowledge of the Bioactivity of Foods in the Diets of Indigenous North Americans (Chapter 5). Bioactive Foods in Promoting Health: Fruits and Vegetables, Elsevier Inc., 2010: 71-84.

[13] Pandey KB and Rizvi SI: Plant polyphenols as dietary antioxidants in human health and disease. Oxidative Medicine and Cellular Longevity, 2009, 2(5): 270-278.

[14] Kris-Etherton PM et al. ; Bioactive compounds in foods: their role in the prevention of cardiovascular disease and cancer. American Journal of Medicine, 2002, 113(Suppl 9B): 71S-88S.

[15] Tejasari D; Evaluation of ginger (Zingiber officinale Roscoe) bioactive compounds in increasing the ratio of T-cell surface molecules of $\mathrm{CD} 3+\mathrm{CD} 4+: \mathrm{CD} 3+\mathrm{CD} 8+$ In-Vitro. Malysian Journal of Nutrition, 2007, 13(2): 161-170.

[16] Denny A and Buttriss J; Plant foods and health: focus on plant bioactives. Synthesis Report No.4, European Food Information Resource (EuroFIR). British Nutrition Foundation. London, 2008: 1-64. 
[17] Liu RH; Potential Synergy of Phytochemicals in Cancer Prevention: Mechanism of Action. Journal of Nutrition, 2004, 134(12S): 3479S-3485S

[18] Sreeramulu D et al.; Natural Antioxidant Activity of Commonly Consumed Plant Foods in India: Effect of Domestic Processing. Oxidative Medicine and Cellular Longevity, 2013 (2013): 1-12.

[19] Klotzbach-Shimomura K ; Herbs and health: safety and effectiveness. Journal of Nutrition Education, 2001, 33 : 354-355.

[20] Willett WC; Balancing life-style and genomics research for disease prevention. Science, 2002, 296: 695-698.

[21] Collier R; Japanese longevity. Canadian Medical Association Journal, 2010, 182(12) : E579.

[22] Hübner F et al. ; The influence of germination conditions on beta-glucan, dietary fibre and phytate during the germination of oats and barley. European Food Research and Technology, 2010, 231(1): 27-35.

[23] Abdel-Aal E and Akhtar MA; Inhibition of Human Ldl Cholesterol by Bioactive Compounds Isolated from Barley and Wheat, 3rd International Conference on Hypertension, Lipids, Diabetes and Stroke Prevention, 2010.

[24] Cavazos A and Gonzalez de Mejia E; Identification of Bioactive Peptides from Cereal Storage Proteins and Their Potential Role in Prevention of Chronic Diseases; Comprehensive Reviews in Food Science and Food Safety, 2013, 12(4): 364 - 380.

[25] Donkor ON et al. ; Germinated grains - Sources of bioactive compounds; Food Chemistry, 2012, 135(3): 950-959.

[26] Jeong HJ et al. ; Lunasin is prevalent in barley and is bioavailable and bioactive in in vivo and in vitro studies; Nutrition and cancer, 2010, 62(8): 1113.

[27] Dia VP and Gonzalez de Mejia E; Potential of Lunasin Orally-Administered in Comparison to Intraperitoneal Injection to Inhibit Colon Cancer Metastasis in Vivo; Journal of Cancer Therapy, 2013, 4: 34-43.

[28] Wang, R et al. ; Nano-encapsulations liberated from barley protein microparticles for oral delivery of bioactive compounds ; International Journal of Pharmaceutics, 2011, 406(1): 153-162.

[29] Panfili G et al. ; Normal phase high-performance liquid chromatography method for the determination of tocopherols and tocotrienols in cereals. Journal of Agricultural and Food Chemistry, 2003, 51(14) : 3940-4.

[30] Sen CK et al. ; Tocotrienol: the natural vitamin E to defend the nervous system? Annals of the New York Academy of Sciences, 2004, 1031: 127-42.

[31] Ling-Xiao G et al. ; Tibetan Hull-less Barley (Hordeum vulgare L.) as a Potential Source of Antioxidants; Cereal Chemistry, 2012, 89(6): 290

[32] Bonoli $\mathrm{M}$ et al. Antioxidant phenols in barley (Hordeum vulgare $L$.) flour: comparative spectrophotometric study among extraction methods of free and bound phenolic compounds. Journal of Agricultural and Food Chemistry, 2004, 52(16): 5195-5200.
[33] Zhao $\mathrm{H}$ et al. ; Evaluation of antioxidant activities and total phenolic contents of typical malting barley varieties. Food Chemistry, 2008, 107(1): 296-304.

[34] Mary O and Qiuhui H; Antioxidant capacity and antioxidative compounds in barley (Hordeum vulgare L.) grain optimized using response surface methodology in hot air roasting; European Food Research and Technology, 2009, 229(6): 907-914.

[35] Lingxiao G et al. ; Effect of Steam Explosion Treatment on Barley Bran Phenolic Compounds and Antioxidant Capacity ; Journal of Agricultural and Food Chemistry, 2012, 60(29): 7177-7184.

[36] Keogh GF et al. Randomized controlled crossover study of the effect of a highly beta-glucan-enriched barley on cardiovascular disease risk factors in mildly hypercholesterolemic men. The American Journal of Clinical Nutrition, 2003, 78(4): 711-718.

[37] Behall KM et al.; Diets containing barley significantly reduce lipids in mildly hypercholesterolemic men and women. The American Journal of Clinical Nutrition, 2004, 80(5): 1185-1193.

[38] Chan WK et al. ; Response of human dendritic cells to different immunomodulatory polysaccharides derived from mushroom and barley; International immunology, 2007, 19(7): 891 - 899.

[39] Sharma $\mathrm{P}$ et al. ; Antioxidant activity of barley as affected by extrusion cooking ; Food Chemistry, 2012, 131(4): 1406

[40] Kumar K et al. ; Physico-chemical and antioxidant properties of extrudates developed from honey and barley ; International Journal of Food Science \& Technology, 2013, 48(8): 1750 1761.

[41] Sharma P and Gujral HS ; Extrusion of Hulled Barley Affecting $\beta$-Glucan and Properties of Extrudates ; Food and Bioprocess Technology, 2013, 6(6): 1374 - 1389.

[42] Sas-Piotrowska B and Piotrowski W ; Vitality and Healthiness of Barley (Hordeum Vulgare L.) Seeds Treated with Plant Extracts. Journal of Plant Protection Research, 2010, 50(1): $117-124$.

[43] Terrence $\mathrm{M}$ and Fereidoon S ; Antioxidant and Antiproliferative Potential of Pearled Barley (Hordeum vulgarae) ; Pharmaceutical Biology 2008, 46(1-2): 88-95.

[44] Jin BJ et al. ; 3,4-Dihydroxybenzaldehyde purified from the barley seeds (Hordeum vulgare) inhibits oxidative DNA damage and apoptosis via its antioxidant activity. Phytomedicine, 2009, 16(1): 85-94.

[45] Paul S et al. ; The increasing use of barley and barley by-products in the production of healthier baked goods. Trends in Food Science \& Technology, 2013, 29(2): 124-134.

[46] Seong-Joon K and Joo SK ; Prebiotics: Germinated barley foodstuff for the prevention of colitis-associated colon cancer? Journal of Gastroenterology and Hepatology, 2011, 26(8): 1219-1220.

[47] Sharma P and Gujral HS ; Extrusion of Hulled Barley Affecting $\beta$-Glucan and Properties of Extrudates ; Food and Bioprocess Technology, 2013, 6(6): $1374-1389$. 
[48] Zhendong $\mathrm{Y}$ and Weiwei Z; Optimization of microwave-assisted extraction of anthocyanins from purple corn (Zea mays L.) cob and identification with HPLC-MS ; Innovative Food Science \& Emerging Technologies, 2010, 11(3): 470-476.

[49] David DPI et al. ; Polyphenolic and antioxidant content of white and blue corn (Zea mays L.) products. Food Research International, 2006, 39(6): 696-703.

[50] Narpinder S et al.; Maize: Composition, Bioactive Constituents, and Unleavened Bread (Chapter 9): Flour and Breads and their Fortification in Health and Disease Prevention, 2011: 89-99.

[51] Romina P and Luis CZ; Phenolic profiles of Andean purple corn (Zea mays L.); Food Chemistry, 2007, 100(3): 956-963.

[52] Liu $\mathrm{J}$ et al. ; The antioxidant and free-radical scavenging activities of extract and fractions from corn silk (Zea mays L.) and related flavone glycosides; Food Chemistry, 2011, 126(1): $261-269$

[53] Zhao Z et al. ; Phenolic antioxidants richly contained in corn bran are slightly bioavailable in rats. Journal of Agricultural and Food Chemistry, 2005, 53(12): 5030-5035.

[54] Pedreschi R and Cisneros-Zevallos L. Antimutagenic and antioxidant properties of phenolic fractions from Andean purple corn (Zea mays L.). Journal of Agricultural and Food Chemistry, 2006, 54(13): 4557-4567.

[55] Sandra MD et al. ; Antioxidant Capacity and Antimutagenic Activity of Anthocyanin and Carotenoid Extracts from Nixtamalized Pigmented Creole Maize Races (Zea mays L.); Plant Foods for Human Nutrition, 2012, 67(4) : 442-449.

[56] Shuhan C et al. ; Chemical modification, antioxidant and $\alpha$-amylase inhibitory activities of corn silk polysaccharides. Carbohydrate Polymers, 2013, 98(1): 428-437.

[57] de Vasconcelos MCBM et al. ; Study of composition, stabilization and processing of wheat germ and maize industrial by-products ; Industrial Crops and Products, 2013, 42: 292 298.

[58] Li JT et al. ; Apoptosis in human hepatoma HepG2 cells induced by corn peptides and its anti-tumor efficacy in H22 tumor bearing mice. Food and chemical toxicology, 2013, 51: $297-305$

[59] Shirley K et al. ; Brazilian Maize Landraces Silks as Source of Lutein: An Important Carotenoid in the Prevention of Age-Related Macular Degeneration. Food and Nutrition Sciences, 2012, 3(11): 1609 - 1614.

[60] Bandeira CM et al. ; Bioactive amines in fresh, canned and dried sweet corn, embryo and endosperm and germinated corn. Food Chemistry, 2012, 131(4): 1355.

[61] Hagiwara A et al. Pronounced inhibition by a natural anthocyanin, purple corn color, of 2-amino-1-methyl -6-phenylimidazo[4,5-b] pyridine (PhIP)-associated colorectal carcinogenesis in male F344 rats pretreated with 1,2-dimethylhydrazine. Cancer Letters, 2001, 171(1): 17-25.

[62] Tsuda $\mathrm{T}$ et al.; Dietary cyanidin 3-O-beta-D-glucoside-rich purple corn color prevents obesity and ameliorates hyperglycemia in mice. Journal of Nutrition, 2003, 133(7): 2125-2130.
[63] Lemcke-Norojarvi $M$ et al. Corn and sesame oils increase serum gamma-tocopherol concentrations in healthy Swedish women. Journal of Nutrition, 2001, 131(4): 1195-1201.

[64] Wagner $\mathrm{KH}$ et al. ; Impact of diets containing corn oil or olive/sunflower oil mixture on the human plasma and lipoprotein lipid metabolism. European Journal of Nutrition, 2001, 40(4): 161-167.

[65] Bangera SM et al. ; Effect of Processing on Major Carotenoid Levels in Corn (Zea mays) and Selected Vegetables: Bioavailability of Lutein and Zeaxanthin from Processed Corn in Mice. Food and Bioprocess Technology, 2010, 1(2): 34.

[66] Rojas-García C et al. ; Chemopreventive Effects of Free and Bound Phenolics Associated to Steep Waters (Nejayote) Obtained After Nixtamalization of Different Maize Types. Plant Foods for Human Nutrition, 2012, 67(1): 94 - 99.

[67] Ostlund RE et al. Phytosterols that are naturally present in commercial corn oil significantly reduce cholesterol absorption in humans. The American Journal of Clinical Nutrition, 2002, 75(6): 1000-1004.

[68] Jenkins AL et al.; Depression of the glycemic index by high levels of beta-glucan fiber in two functional foods tested in type 2 diabetes. European Journal of Clinical Nutrition, 2002, 56: 622-628.

[69] Tapola $\mathrm{N}$ et al.; Glycemic responses of oat bran products in type 2 diabetic patients. Nutrition, Metabolism and Cardiovascular Diseases., 2005, 15: 255-261.

[70] Thomas MSW et al.; Bioactive oat [beta]-glucan reduces LDL cholesterol in Caucasians and non-Caucasians, Nutrition Journal, 2011, 10(1): 130.

[71] Redaelli R et al.; Naked oats for improving human nutrition: genetic and agronomic variability of grain bioactive components, Crop Science, 2009, 49(4): 1431.

[72] Ryan L et al.; Oat-based breakfast cereals are a rich source of polyphenols and high in antioxidant potential, Journal of Food Composition and Analysis, 2011, 24(7): 929-934.

[73] El Khoury et al.; Beta glucan: health benefits in obesity and metabolic syndrome, Journal of nutrition and metabolism, 2012 2012: 851362- 28 .

[74] Ilva N and al., Detection of the lunasin peptide in oats (Avena sativa L), Journal of Cereal Science, 2013, 57(3): 319.

[75] Lin PY and Lai HM ; Bioactive compounds in rice during grain development. Food Chemistry, 2011, 127(1): 86 - 93.

[76] Qureshi AA et al. Dose-dependent suppression of serum cholesterol by tocotrienol-rich fraction (TRF25) of rice bran in hypercholesterolemic humans. Atherosclerosis 2002, 161(1) : 199-207.

[77] Ham $\mathrm{H}$ et al. ; Antioxidant activities and contents of phytochemicals in methanolic extracts of specialty rice cultivars in Korea. Food Science and Biotechnology, 2013, 22(3): $631-637$.

[78] Moongngarm A and Saetung N; Comparison of chemical compositions and bioactive compounds of germinated rough rice and brown rice. Food Chemistry, 2010, 122(3): 782 - 788.

[79] Forster GM et al. ; Rice varietal differences in bioactive bran components for inhibition of colorectal cancer cell growth. Food chemistry, 2013, 141(2): 1545. 
[80] Usuki S et al. ; IGF-1 induction by acylated steryl $\beta$-glucosides found in a pre-germinated brown rice diet reduces oxidative stress in streptozotocin-induced diabetes; PloS one, 2011, 6(12): e28693.

[81] Huang SH and Ng LT; Quantification of polyphenolic content and bioactive constituents of some commercial rice varieties in Taiwan. Journal of Food Composition and Analysis, 2012, 26(1-2): $122-127$.

[82] Yang L and Kadowaki M; Effects of rice proteins from two cultivars, Koshihikari and shunyo, on hepatic cholesterol secretion by isolated perfused livers of rats fed cholesterol-enriched diets. Annals of Nutrition and Metabolism, 54: $283-290$.

[83] Manosroi A et al. ; Relationship between biological activities and bioactive compounds in the fermented rice sap. Food Research International, 2011, 44(9): 2757 - 2765.

[84] Imam MU et al. ; Effects of germinated brown rice and its bioactive compounds on the expression of the peroxisome proliferator-activated receptor gamma gene; Nutrients, 2013, 5(2): $468-477$.

[85] Iqbal $\mathrm{J}$ et al. ; Suppression of 7,12-dimethylbenz[alpha] anthracene-induced carcinogenesis and hypercholesterolaemia in rats by tocotrienol-rich fraction isolated from rice bran oil. European Journal of Cancer Prevention, 2003, 12(6): 447-453.

[86] Qureshi AA et al. Isolation and identification of novel tocotrienols from rice bran with hypocholesterolemic, antioxidant, and antitumor properties. Journal of Agricultural and Food Chemistry, 2000, 48(8):3130-40.

[87] Hudson EA et al. Characterization of potentially chemopreventive phenols in extracts of brown rice that inhibit the growth of human breast and colon cancer cells. Cancer Epidemiology, Biomarkers \& Prevention, 2000, 9(11): 1163-1170.

[88] Kentaro $\mathrm{M}$ et al. ; Investigation of tocotrienol biosynthesis in rice (Oryza sativa L.). Food Chemistry, 2013, 140(1-2): 91-98.

[89] Oghbaei M and Prakash J ; Effect of compositional alteration of food matrices and processing on availability of selected nutrients and bioactive components in rice products. International journal of food sciences and nutrition, 2011, 62(3): 250-261.

[90] Wang Q et al. ; Supplementation of black rice pigment fraction improves antioxidant and anti-inflammatory status in patients with coronary heart disease. Asia Pacific Journal of Clinical Nutrition, 2007, 16: $295-301$.

[91] Zubair M et al. ; Characterization of High-Value Bioactives in Some Selected Varieties of Pakistani Rice (Oryza sativa L.). International journal of molecular sciences, 2012, 13(4): 4608 4622 .

[92] Norazalina S et al. ; Anticarcinogenic efficacy of phytic acid extracted from rice bran on azoxymethane-induced colon carcinogenesis in rats. Experimental and Toxicologic Pathology, 2010, 62: 259-268.

[93] Hsu TF et al. ; Effects of Pre-Germinated Brown Rice on Blood Glucose and Lipid Levels in Free-Living Patients with Impaired Fasting Glucose or Type 2 Diabetes. Journal of Nutritional Science and Vitaminology, 2008, 54: 163 - 168.
[94] Imam MU and Ismail M ; Nutrigenomic effects of germinated brown rice and its bioactives on hepatic gluconeogenic genes in type 2 diabetic rats and HEPG2 cells. Molecular nutrition \& food research, 2013, 57(3): 401.

[95] Kim JY et al. ; Meal replacement with mixed rice is more effective than white rice in weight control, while improving antioxidant enzyme activity in obese women. Nutrition Research, 2008, 28: 66 - 71 .

[96] Yoshiyuki M et al. ; Cycloartenyl trans-ferulate, a component of the bran byproduct of sake-brewing rice, inhibits mammalian DNA polymerase and suppresses inflammation. Food Chemistry, 2013, 141(2): 1000-1007.

[97] Cheng HH et al. ; Ameliorative effects of stabilized rice bran on type 2 diabetes patients. Annals of Nutrition and Metabolism, $2010,56: 45-51$.

[98] $\mathrm{Hu} \mathrm{C}$ et al. Black rice (Oryza sativa L. indica) pigmented fraction suppresses both reactive oxygen species and nitric oxide in chemical and biological model systems. Journal of Agricultural and Food Chemistry, 2003, 51(18): 5271-5277.

[99] Ho TF and Yip WC ; Oral rehydration solution: Rice water is cheap and effective. British Medical Journal , 2001, 323(7320) : 1068 .

[100] Silva CR et al. ; Effect of a rice bran fiber diet on serum glucose levels of diabetic patients in Brazil ; Archivos Latinoamericanos de Nutricion, 2005, 55: 23-27.

[101] Byungrok $\mathrm{M}$ et al. ; Free and bound total phenolic concentrations, antioxidant capacities, and profiles of proanthocyanidins and anthocyanins in whole grain rice (Oryza sativa L.) of different bran colours. Food Chemistry, 2012, 133(3) :715-722.

[102]Lee YR et al. ; Cholesterol-lowering and antioxidant status-improving efficacy of germinated giant embryonic rice (Oryza sativa L.) in high cholesterol-fed rats. Annals of Nutrition and Metabolism, 2007, 51: 519-526.

[103] Roohinejad S et al. ; Effect of pre-germination time of brown rice on serum cholesterol levels of hypercholesterolaemic rats. Journal of the Science of Food and Agriculture, 2010, 90: 245 251.

[104] Pei-Ni C et al. ; Black rice anthocyanins inhibit cancer cells invasion via repressions of MMPs and u-PA expression. Chemico-Biological Interactions, 2006, 163(3): 218-229.

[105] Lee KW et al. ; The effects of goami No. 2 rice, a natural fiber-rich rice, on body weight and lipid metabolism. Obesity, 2006, 14: 423-430.

[106] Kanauchi O et al. ; Preventive effects of enzyme-treated rice fiber in a restraint stress-induced irritable bowel syndrome model. International Journal of Molecular Medicine, 2010, 25 : $547-555$.

[107] Lei L et al. ; Phospholipids in rice: Significance in grain quality and health benefits: A review. Food Chemistry, 2013, 139(1-4) : 1133-1145.

[108] Sankam P et al.; Antimutagenicity and anticlastogenicity of glutinous purple rice hull using in vitro and in vivo testing systems. Molecular \& Cellular Toxicology, 2013, 9(2): 169 176. 
[109] Wu F et al. ; Germinated brown rice and its role in human health. Critical reviews in food science and nutrition, 2013, 53(5): 451.

[110] Deng GF et al. ; Phenolic compounds and bioactivities of pigmented rice. Critical reviews in food science and nutrition, 2013, 53(3): 296.

[111] Lee CI et al. ; Monascus-fermented red mold rice exhibits cytotoxic effect and induces apoptosis on human breast cancer cells. Applied microbiology and biotechnology, 2013, 97(3): $1269-1278$.

[112] Kaup RM et al. ; Antidiabetic Effects of a Standardized Egyptian Rice Bran Extract. Phytotherapy Research, 2013, 27(2): 264-271.

[113] Mohanlal S et al. ; Tricin 4'-O-(erythro- $\beta$-guaiacylglyceryl) ether and tricin 4'-O-(threo- $\beta$-guaiacylglyceryl) ether isolated from Njavara (Oryza sativa L. var. Njavara), induce apoptosis in multiple tumor cells by mitochondrial pathway. Journal of natural medicines, 2013, 67(3): 528 - 533.

[114] Tanwir F et al. ; Comparison of the levels of bioactive benzoxazinoids in different wheat and rye fractions and the transformation of these compounds in homemade foods. Food chemistry, 2013, 141(1): 444.

[115] Ji X et al. ; Very long chain alkylresorcinols accumulate in the intracuticular wax of rye (Secale cereale L.) leaves near the tissue surface. Phytochemistry, 2008, 69(5): 1197-1207.

[116] Pedersen HA et al. ; Bread from common cereal cultivars contains an important array of neglected bioactive benzoxazinoids. Food Chemistry, 2011, 127(4): 1814 - 1820.

[117] Adhikari KB et al. ; Bioactive benzoxazinoids in rye bread are absorbed and metabolized in pigs. Journal of agricultural and food chemistry, 2012, 60(10): 2497.

[118] Juntunen KS, Mazur WM, et al. Consumption of wholemeal rye bread increases serum concentrations and urinary excretion of enterolactone compared with consumption of white wheat bread in healthy Finnish men and women. British Journal of Nutrition, 2000, 84(6): 839-846.

[119] Jeong HJ et al. ; The cancer preventive seed peptide lunasin from rye is bioavailable and bioactive ; Nutrition and cancer, 2009, 61(5): 680 - 686

[120] Wikstrom P, Bylund A, et al. Rye bran diet increases epithelial cell apoptosis and decreases epithelial cell volume in TRAMP (transgenic adenocarcinoma of the mouse prostate) tumors. Nutr Cancer, 2005, 53(1): 111-116.

[121] Pietinen P et al.; Serum enterolactone and risk of breast cancer: a case-control study in eastern Finland. Cancer Epidemiology, Biomarkers \& Prevention, 2001, 10(4): 339-344.

[122] Liukkonen KH et al. ; Process-induced changes on bioactive compounds in whole grain rye; The Proceedings of the Nutrition Society, 2003, 62(1): 117-122.

[123] Linko AM, Juntunen KS, et al. Whole-grain rye bread consumption by women correlates with plasma alkylresorcinols and increases their concentration compared with low-fiber wheat bread. Journal of Nutrition, 2005, 135(3): 580-583.

[124] Michalska A et al. ; Bioactive compounds in rye flours with different extraction rates; European Food Research and Technology, 2007, 225(3): 545 - 551.
[125] Andreasen MF, Landbo AK, et al. Antioxidant effects of phenolic rye (Secale cereale L.) extracts, monomeric hydroxycinnamates, and ferulic acid dehydrodimers on human low-density lipoproteins. Journal of Agricultural and Food Chemistry, 2001, 49(8): 4090-4096.

[126] Leinonen KS et al.; Rye bread decreases serum total and LDL cholesterol in men with moderately elevated serum cholesterol. Journal of Nutrition, 2000, 130(2): 164-170.

[127] Shewry PR et al.; Effects of genotype and environment on the content and composition of phytochemicals and dietary fiber components in rye in the healthgrain diversity screen. Journal of agricultural and food chemistry, 2010, 58(17): 9372.

[128] Hallmans G et al. Rye, lignans and human health. Proceedings Of The Nutrition Society 2003, 62(1): 193-199.

[129] Hanhineva $\mathrm{K}$ et al.; Qualitative characterization of benzoxazinoid derivatives in whole grain rye and wheat by LC-MS metabolite profiling; Journal of agricultural and food chemistry, 2011, 59(3): 921.

[130] Rosén LAH et al. ; Postprandial glycemia, insulinemia, and satiety responses in healthy subjects after whole grain rye bread made from different rye varieties ; Journal of agricultural and food chemistry, 2011, 59(22): 12139.

[131]Zieliński $\mathrm{H}$ et al. ; Antioxidant contents and properties as quality indices of rye cultivars ; Food Chemistry, 2007, 104(3): 980-988.

[132] Michalska A et al.; Antioxidant contents and antioxidative properties of traditional rye breads ; Journal of agricultural and food chemistry, 2007, 55(3): 734 - 740.

[133] Macías FA et al. ; Rediscovering the bioactivity and ecological role of 1,4-benzoxazinones ; Natural product reports, 2009, 26(4): 478 - 489.

[134] Zasada IA et al. ; Improving the use of rye (Secale cereale) for nematode management: potential to select cultivars based on Meloidogyne incognita host status and benzoxazinoid content. Nematology, 2007, 9(1): 53 - 53.

[135] Juntunen KS, Laaksonen DE, et al. High-fiber rye bread and insulin secretion and sensitivity in healthy postmenopausal women. The American Journal of Clinical Nutrition, 2003, 77(2): 385-391.

[136] Grasten SM et al.; Rye bread improves bowel function and decreases the concentrations of some compounds that are putative colon cancer risk markers in middle-aged women and men. Journal of Nutrition, 2000, 130(9): 2215-2221.

[137] Rosén La et al. ; Effects of cereal breakfasts on postprandial glucose, appetite regulation and voluntary energy intake at a subsequent standardized lunch; focusing on rye products ; Nutrition journal, 2011, 10(1): 7.

[138] Heiniö RL et al. ; Quantities of phenolic compounds and their impacts on the perceived flavour attributes of rye grain. Journal of Cereal Science, 2008, 47(3): 566 - 575.

[139] Capuano E et al.; Rye Flour Extraction Rate Affects Maillard Reaction Development, Antioxidant Activity, and Acrylamide Formation in Bread Crisps; Cereal Chemistry, 2010, 87(2): 100315091533001-136.

[140] Nurhan TD and Jeff E, Nutritional bioactive components of wheat straw as affected by genotype and environment, Bioresource technology, 2010, 101(1): 422 - 425. 
[141] Adom KK et al.; Phytochemicals and antioxidant activity of milled fractions of different wheat varieties. Journal of Agricultural and Food Chemistry, 2005, 53(6): 2297-306.

[142] Adom KK et al.; Phytochemical profiles and antioxidant activity of wheat varieties. Journal of Agricultural and Food Chemistry, 2003, 51(26): 7825-7834.

[143] Zhou K et al.; Phenolic acid, tocopherol and carotenoid compositions, and antioxidant functions of hard red winter wheat bran. Journal of Agricultural and Food Chemistry, 2005, 53(10): 3916-3922.

[144] Ross AB et al.; Dietary alkylresorcinols: absorption, bioactivities, and possible use as biomarkers of whole-grain wheat- and rye-rich foods. Nutrition Reviews, 2004, 62(3): 81-95.

[145] Liyana-Pathirana CM and Shahidi F; Antioxidant activity of commercial soft and hard wheat (Triticum aestivum L.) as affected by gastric $\mathrm{pH}$ conditions. Journal of Agricultural and Food Chemistry, 2005, 53(7): 2433-2440.

[146] Jenkins DJ et al.; Effect of wheat bran on glycemic control and risk factors for cardiovascular disease in type 2 diabetes. Diabetes Care, 2002, 25(9): 1522-1528.

[147] Ostlund RE Jr et al.; Inhibition of cholesterol absorption by phytosterol-replete wheat germ compared with phytosterol-depleted wheat germ. The American Journal of Clinical Nutrition, 2003, 77(6): 1385-1389.

[148] Ferguson LR and Harris PJ; Protection against cancer by wheat bran: role of dietary fibre and phytochemicals. European Journal of Cancer Prevention, 1999, 8(1): 17-25.

[149] El-Sayed MA and Iwona R; Bioactive Compounds and their Antioxidant Capacity in Selected Primitive and Modern Wheat Species, The Open Agriculture Journal, 2008, 2(1): 7-14.

[150] Roberto C et al.; Content and relative composition of some phytochemicals in diploid, tetraploid and hexaploid Triticum species with potential nutraceutical properties. Journal of Cereal Science, 2013, 57(2): 5-17.

[151] Mitsuru W and Jun A; Effects of buckwheat sprouts on plasma and hepatic parameters in type 2 diabetic $\mathrm{db} / \mathrm{db}$ mice; Journal of food science, 2010, 75(9): H294 - H299.

[152] Yingdong Z et al. ; Structure Elucidation and Chemical Profile of Sphingolipids in Wheat Bran and Their Cytotoxic Effects against Human Colon Cancer Cells. Journal of Agricultural and Food Chemistry, 2013, 61(4): 866-874.

[153] Jonnala RS et al.; Phenolics in the bran of waxy wheat and triticale lines; Journal of Cereal Science, 2010, 52(3): 509 515.

[154] Hromádková Z et al.; Structural features of two heteroxylan polysaccharide fractions from wheat bran with anti-complementary and antioxidant activities. Carbohydrate polymers, 2013, 93(1): 22 .

[155] Nurmi T et al. ; Distribution and composition of phytosterols and steryl ferulates in wheat grain and bran fractions ; Journal of Cereal Science, 2012, 56(2): 379.

[156] Anonymous ; Waste: A source of bioactive compounds, Biotechnology Journal, 2008, 3(7) : 1.

[157] Naczk $M$ and Shahidi F ; Phenolics in cereals, fruits and vegetables: occurrence, extraction and analysis. J Pharm Biomed Anal, 2006, 41:1523-1542.
[158] Song LJ et al. ; Purification of major glucosinolates from Brassicaceae seeds and preparation of isothiocyanate and amine metabolites. Journal of the Science of Food and Agriculture, 2006, 86(8): 1271-1280.

[159] Marín A et al. ; Characterization and quantification of antioxidant constituents of sweet pepper (Capsicum annuum L.). Journal of Agricultural and Food Chemistry, 2004, 52: $3861-3869$

[160] Bordiga $\mathrm{M}$ et al.; Characterisation of polymeric skin and seed proanthocyanidins during ripening in six Vitis vinifera L. cv. food chemistry, 2011, 127(1): 180-187.

[161] Anttonen MJ and Karjalainen RO; Environmental and genetic variation of phenolic compounds in red raspberry; Journal of Food Composition and Analysis, 2005, 18(8): 759-769.

[162] Mori K et al. ; Loss of anthocyanins in red-wine grape under high temperature. Journal of Experimental Botany, 2007, 58(8): 1935-1945.

[163] Negi PS ; Plant extracts for the control of bacterial growth: Efficacy, stability and safety issues for food application. International journal of Food Microbiology, 2012, 156(1): $7-17$.

[164] White DA et al.; Characterisation of oat (Avena sativa L.) oil bodies and intrinsically associated E-vitamers. Journal of Cereal Science, 2006, 43(2): 244-249.

[165] Horvath G et al.; Accumulation of tocopherols and tocotrienols during seed development of grape (Vitis vinifera L. cv. Albert Lavallée). Plant Physiology and Biochemistry, 2006, 44(11-12): 724-731.

[166] Lampi AM et al.; Tocopherols and Tocotrienols from Oil and Cereal Grains: Functional Foods - Biochemical and Processing Aspects. CRC Press: Boca Raton 2002: 1-38.

[167] Munne-Bosch S and Alegre L; The function of tocopherols and tocotrienols in plants. Critical Reviews in Plant Sciences, 2002, 21(1): 31-57.

[168] Falk J and Munné-Bosch S; Tocochromanol functions in plants: antioxidation and beyond. Journal of Experimental Botany, 2010, 61(6): 1549-1566.

[169] Panfili G et al.; Normal phase high-performance liquid chromatography method for the determination of tocopherols and tocotrienols in cereals. Journal of Agricultural and Food Chemistry, 2003, 51(14): 3940-3944.

[170] Tiwari U and Cummins E; Nutritional importance and effect of processing on tocols in cereals. Trends in Food Science and Technology, 2009, 20(11-12): 511-520.

[171] Liu RH; Whole grain phytochemicals and health. Journal of Cereal Science, 2007, 46(3): 207-219.

[172] Bernhoft A ; A brief review on bioactive compounds in plants. In : Bioactive compounds in plants - benefits and risks for man and animals; Oslo: The Norwegian Academy of Science and Letters, 2010 : 11-17.

[173] Adlercreutz $\mathrm{H}$; Phytoestrogens and human health. In: Bioactive compounds in plants - benefits and risks for man and animals. Oslo: The Norwegian Academy of Science and Letters, $2010: 78-93$. 
[174] Smeds AI et al. ; Characterization of variation in the lignan content and composition of winter rye, spring wheat, and spring oat. Journal of Agricultural and Food Chemistry 2009, 57: $5837-5842$.

[175] Ragaee S et al. ; Bioactive Components and Antioxidant Capacity of Ontario Hard and Soft Wheat varieties. Canadian Journal of Plant Science. 2012, 92(1): 19-30.

[176] Ragaee S et al. ; Impact of milling and thermal processing on phenolic compounds in cereal grains. Critical Reviews in Food Science and Nutrition, 2014, 54(7): 837-849.

[177] Kaukovirta-Norja A et al. ; Germination: a means to improve the functionality of oat. Agricultural and Food Science, 2004, 13(1-2): 100-112.

[178] Cunha WR et al. ; Lignans: Chemical and Biological Properties : Phytochemicals - A Global Perspective of Their Role in Nutrition and Health (chapter 10). InTech, 2012: 213-234.

[179] Milder IEJ et al. ; Lignan contents of Dutch plant foods: a database including lariciresinol, pinoresinol, secoisolariciresinol and matairesinol. British Journal of Nutrition, 2005, 93: 393-402.

[180] Smeds AI et al. ; Quantification of a Broad Spectrum of Lignans in Cereals, Oilseeds, and Nuts. Journal of Agricultural and Food Chemistry, 2007, 55: 1337-1346.

[181] Webb ML and McCullough ML ; Dietary Lignans: Potential role in cancer prevention, nutrition and cancer. 2005, 51: $117-131$.

[182] Pan A et al. ; Effects of a flaxseed-derived lignan supplement on C-reactive protein, IL- 6 and retinol-binding protein 4 in type 2 diabetic patients. British Journal of Nutrition, 2009, 101: $1145-1149$.

[183] Adolphe JL et al. ; Health effects with consumption of the flax lignan secoisolariciresinol diglucoside. British Journal of Nutrition, 2010, 103: 929-938.

[184] Li Y et al. ; Bioactive Neolignans and Lignans from the Bark of Machilus robusta. Journal of Natural Products, 2011, 74: 1444-1452.

[185] Eckert E et al. ; Biologically active peptides derived from egg proteins; World's Poultry Science Journal, 2013, 69(2): 375.

[186] Chen C and Chi YJ; Antioxidant, ace inhibitory activities and functional properties of egg white protein hydrolysate. Journal of Food Biochemistry, 2012, 36 (4): 383-394.

[187] Oliveira GE et al. ; Bioactive amines and quality of egg from Dekalb hens under different storage conditions; Poultry science, 2009, 88(11): 2428.

[188] Kaustav M et al. ; Structure and Activity Study of Egg Protein Ovotransferrin Derived Peptides (IRW and IQW) on Endothelial Inflammatory Response and Oxidative Stress; Journal of Agricultural and Food Chemistry, 2013, 61(9): 2120-2129.

[189] Strixner T and Kulozik U ; Egg proteins (Chapter 7): handbook of food proteins, Woodhead Publishing, 2011: 150-209.

[190] Goodrow EF et al. Increases Serum Lutein and Zeaxanthin Concentrations in Older Adults without Altering Serum Lipid and Lipoprotein Cholesterol Concentrations, Journal of Nutrition, 2006, $136: 2519-2524$.
[191] Mine Y et al. ; Antimicrobial peptides released by enzymatic hydrolysis of hen egg white lysozyme. Journal of Agricultural and Food Chemistry, 2004, 52: 1088-1094.

[192] Nakane S et al. ; Hen egg yolk and white contain high amounts of lysophosphatidic acids, growth factor - like lipids: Distinct molecule species compositions. Lipid, 2001, 36(4): 413 - 419.

[193] Anton N et al. ; Bioactive egg components and their potential uses; World's Poultry Science Journal, 2006, 62(3): 429 - 438.

[194] Mine Y and D'Silva I; Bioactive Components in Egg White (Chapter 4): Egg Bioscience and Biotechnology, John Wiley \& Sons, Inc., 2008: 141-184.

[195] Hatta H et al. ; Bioactive Components in Egg Yolk (Chapter 5): Egg Bioscience and Biotechnology, John Wiley \& Sons, Inc., 2008: 185-237.

[196] Zeisel SH. Choline: needed for normal development of memory. Journal of the American College of Nutrition., 2000, 19: 528S-531S.

[197] Ayadi MA et al. ; Effect of Moderate Spray Drying Conditions on Functionality of Dried Egg White and Whole Egg ; Journal of Food Science, 2008, 73(6): E281-E287.

[198] Florence B and Sophie R; Compounds with Antibacterial Activity (Chapter 23): Bioactive Egg Components, (Springer) 2007: 191-198.

[199] Rosina LF et al.; Egg-Protein-Derived Peptides with Antihypertensive Activity (Chapter 24), in: Bioactive Egg Components, Springer, 2007: 199-212.

[200] Fahey JW and Stephenson KK. Pinostrobin from honey and Thai ginger (Boesenbergia pandurata): a potent flavonoid inducer of mammalian phase 2 chemoprotective and antioxidant enzymes. Journal of Agricultural and Food Chemistry, 2002, 50(25): 7472-7476.

[201] Biesaga M and Pyrzyńska K; Stability of bioactive polyphenols from honey during different extraction methods; Food chemistry, 2013, 136(1): 46.

[202] Bogdanov S et al. ; Honey for nutrition and health: a review.; Journal of the American College of Nutrition. 2008, 27(6): 677-689.

[203] Morales P and Haza AI ; Antiproliferative and apoptotic effects of spanish honeys; Pharmacognosy Magasine, 2013, 9(35): 231-237.

[204] Ajibola A et al.; Nutraceutical values of natural honey and its contribution to human health and wealth; Nutrition \& Metabolism. 2012, 9:61.

[205] Eteraf-Oskouei T and Najafi M ; Traditional and modern uses of natural honey in human diseases: a review. Iranian Journal of Basic Medical Sciences, 2013, 16(6):731-742.

[206] Ezz El-Arab AM et al.; Effect of dietary honey on intestinal microflora and toxicity of mycotoxins in mice. BMC Complementary and Alternative Medicine., 2006, 6: 1-13.

[207] Sewllam T et al. ; Antineoplastic activity of honey in an experimental bladder cancer implantation model: in vivo and in vitro studies. International Journal of Urology, 2003, 10: 213-219.

[208] Alvarez-Suarez JM et al.; Contribution of honey in nutrition and human health: a review; Mediterranean Journal of Nutrition and Metabolism, 2010, 3(1): 15-23. 
[209] Rakha MK et al. ; Cardioactive and vasoactive effects of natural wild honey against cardiac malperformance induced by hyperadrenergic activity. Journal of Medicinal Food., 2008, 11: 91-98.

[210] Al-Mamary M et al. ; Antioxidant activities and total phenolics of different types of honey. Nutrition Research., 2002, 22: $1041-1047$.

[211] Al-Waili NS and Haq A; Effect of honey on antibody production against thymus-dependent and thymus-independent antigens in primary and secondary immune responses. Journal of Medicinal Food, 2004, 7: 491-494.

[212] Medhi B et al. ; Topical application of honey in the treatment of wound healing: a meta analysis. JK Science, 2008, 10: 166-169.

[213] Hegazi AG and Abd El-Hady FK. Influence of honey on the suppression of human low density lipoprotein (LDL) peroxidation (in vitro) Evid Based BMC Complementary and Alternative Medicine., 2009, 6: 113-121.

[214] Sampath Kumar KP et al.; Medicinal uses and health benefits of Honey: An overview. Journal of Chemical and Pharmaceutical Research, 2010, 2: 385-395.

[215] Molan P; Why honey is effective as a medicine. 2. The scientific explanation of its effects; Bee World, 2001, 82: $22-40$.

[216] Munstedt K et al.; Effect of honey on serum cholesterol and lipid values. Journal of Medicinal Food, 2009, 12(3): 624-628.

[217] Cortés ME et al. ; The medicinal value of honey: A review on its benefits to human health, with a special focus on its effects on glycemic regulation. Ciencia e investigación agraria, 2011, 38: 303-317.

[218] Chan CW et al. ; Analysis of the flavonoid component of bioactive New Zealand mānuka (Leptospermum scoparium) honey and the isolation, characterisation and synthesis of an unusual pyrrole. Food chemistry, 2013, 141(3): 1772-1781.

[219] Amudha K and Sunil G ; Potential benefits of honey in type 2 diabetes mellitus: A review ; International Journal of Collaborative Research on Internal Medicine \& Public Health, 2013, 5(4): 199.

[220] Dong R et al. ; Phenolic Profiles and Antioxidant Capacities of Chinese Unifloral Honeys from Different Botanical and Geographical Sources. Food and Bioprocess Technology, 2013, 6(3): $762-770$.

[221] Wang J and Li QX; Chemical composition, characterization, and differentiation of honey botanical and geographical origins. Advances in Food Nutrition Research, 2011, 62 : 89-137.

[222] Motard-Bélanger A et al. Study of the effect of trans fatty acids from ruminants on blood lipids and other risk factors for cardiovascular disease. The American Journal of Clinical Nutrition, 2008, 87: 593-599.

[223] Tseng $M$ et al. Dairy, calcium, and vitamin D intakes and prostate cancer risk in the National Health and Nutrition Examination Epidemiologic Follow-up Study Cohort. The American Journal of Clinical Nutrition, 2005, 81: 1147-1154.

[224] Richard B Kreider et al.; Bioactive properties and clinical safety of a novel milk protein peptide, Nutrition Journal, 2011, 10: 99.
[225] Emily H and Rattan C; Antihypertensive and antimicrobial bioactive peptides from milk proteins, European Food Research and Technology, 2008, 227(1): 7-15.

[226] Lönnerdal B; Bioactive proteins in breast milk; Journal of Paediatrics and Child Health, 2013, 49: 1-7.

[227] German JB et al.; Bioactive components in milk; Current opinion in clinical nutrition and metabolic care, 2002, 5(6): 653-658.

[228] Livney YD; Milk proteins as vehicles for bioactives; Current Opinion in Colloid \& Interface Science, 2010, 15(1): 73-83.

[229] Pfeuffer M and Schrezenmeir J. Bioactive substances in milk with properties decreasing risk of cardiovascular diseases. British Journal of Nutrition, 2000, 84(Supp11): S155-S159.

[230] Groziak SM and Miller GD. Natural bioactive substances in milk and colostrum: effects on the arterial blood pressure system. British Journal of Nutrition, 2000, 84(Suppl1): S119-S125.

[231] Gopal PK et al.; Oligosaccharides and glycoconjugates in bovine milk and colostrum. British Journal of Nutrition, 2000, 84(Suppl 1): S69-S74.

[232] Molkentin J; Occurrence and biochemical characteristics of natural bioactive substances in bovine milk lipids. British Journal of Nutrition, 2000, 84(Suppl 1): S47-S53.

[233] Shah NP; Effects of milk-derived bioactives: an overview. British Journal of Nutrition, 2000, 84(Suppl 1): S3-S10.

[234] Donnet-Hughes A et al. Bioactive molecules in milk and their role in health and disease: the role of transforming growth factor-beta. Immunology \& Cell Biology, 2000, 78: 74-79.

[235] Sjogren P et al.; Milk-derived fatty acids are associated with a more favorable LDL particle distribution in healthy men. Journal of Nutrition, 2004, 134: 1729-1735.

[236] Marta D et al.; Milk proteins as precursors of bioactive peptides; Acta Scientiarum Polonorum: Technologia Alimentaria, 2009, 8(1): $71-90$.

[237] Mills S el al.; Milk intelligence: Mining milk for bioactive substances associated with human health; International Dairy Journal, 2011, 21(6): 377- 401.

[238] Chatterton DEW et al.; Anti-inflammatory mechanisms of bioactive milk proteins in the intestine of newborns; The international journal of biochemistry \& cell biology, 2013, 45(8): $1730-1747$.

[239] Hannu JK; Bioactive milk proteins and peptides: from science to functional applications; Australian Journal of Dairy Technology, 2009, 64(1): 16.

[240] Angela MR et al.; Milk bioactives: discovery and proof of concept; Australian Journal of Dairy Technology, 2005, 60(2): 114.

[241] Srinivas S and Prakash V; Bioactive Peptides from Bovine Milk $\alpha$-Casein: Isolation, Characterization and Multifunctional properties; International Journal of Peptide Research and Therapeutics; 2010, 16(1): 7-15.

[242] Jelen P ; Book Review : Bioactive Components in Milk and Dairy Products. International Dairy Journal, 2010, 20(8): 560. 
[243] Ness AR et al. Advice to eat fish and mood: a randomised controlled trial in men with angina. Nutritional Neuroscience, 2003, 6(1): 63-65.

[244] Del Gobbo LC et al. ; Risks and benefits of fish consumption for childbearing women. Canadian Journal of Dietetic Practice and Research, Spring, 2010, 71(1): 41-45.

[245] Morris MC et al. Consumption of fish and n-3 fatty acids and risk of incident Alzheimer disease. Archives of neurology, 2003, 60(7): 940-946.

[246] Mozaffarian D and Rimm EB; Fish intake, contaminants, and human health: evaluating the risks and the benefits. JAMA, 2006, 296(15): 1885-99. Erratum in JAMA. 2007, 297(6): 590.

[247] Mozaffarian D et al. Fish consumption and stroke risk in elderly individuals: the cardiovascular health study. Archives of Internal Medicine, 2005, 165(2): 200-206.

[248] Se-Kwon K and Ramjee P; Medicinal Foods from Marine Animals: Current Status and Prospects (Chapter 1): Marine Medicinal Foods - Implications and Applications - Animals and Microbes; Advances in Food and Nutrition Research, 2012, 65: 1-9.

[249] Sands SA et al. The impact of age, body mass index, and fish intake on the AEP and ADH content of human erythrocytes. Lipids, 2005, 40(4): 343-347.

[250] Yuan JM et al. Fish and shellfish consumption in relation to death from myocardial infarction among men in Shanghai, China. American Journal of Epidemiology., 2001, 154: 809-816.

[251] Mahanama DZ; Medicinal Benefits of Marine Invertebrates: Sources for Discovering Natural Drug Candidates (Chapter 9): Marine Medicinal Foods - Implications and Applications Animals and Microbes; Advances in Food and Nutrition Research, 2012, 65: 153-169.

[252] Calder PC. n-3 Fatty acids and cardiovascular disease: evidence explained and mechanisms explored. Clinical Science, 2004, 107: 1-11.

[253] Kris-Etherton PM et al. Omega-3 fatty acids and cardiovascular disease: new recommendations from the American Heart Association. Arteriosclerosis, Thrombosis, and Vascular Biology, 2003, 23: 151-152.

[254] Duarte $\mathrm{J}$ et al. ; Immunomodulating capacity of commercial fish protein hydrolysate for diet supplementation. Immunobiology, 2006, 211: 341-350.

[255] Mori TA et al. Purified eicosapentaenoic and docosahexaenoic acids have differential effects on serum lipids and lipoproteins, LDL particle size, glucose, and insulin in mildly hyperlipidemic men. The American Journal of Clinical Nutrition, 2000, 71(5): 1085-1094.

[256] Se-Kwon K and Quang VT ; Bioactive Sterols from Marine Resources and Their Potential Benefits for Human Health (Chapter 17): Marine Medicinal Foods - Implications and Applications - Animals and Microbes; Advances in Food and Nutrition Research, 2012, 65: 261-268.

[257] Wergedahl $\mathrm{H}$ et al. ; Fish protein hydrolysate reduces plasma total cholesterol, increases the proportion of HDL cholesterol, and lowers acyl-CoA:cholesterol acyltransferase activity in liver of Zucker rats. Journal of Nutrition, 2004, 134:1320-1327.
[258] Higuera-Ciapara L et al. ; Astaxanthin: A Review of its Chemistry and Applications. Critical Reviews in Food Science and Nutrition, 2006, 46:185-196.

[259] Patrick ME et al. ; The pharmaceutical value of marine biodiversity for anti-cancer drug discovery; Ecological Economics, 2010, 70(2): 445-451.

[260] Mahinda S and Se-Kown K; Development of Bioactive Peptides from Fish Proteins and Their Health Promoting Ability (Chapter 15): Marine Medicinal Foods - Implications and Applications - Animals and Microbes; Advances in Food and Nutrition Research, 2012, 65: 235-248.

[261] Se-Kwon K et al.; Marine Fish-Derived Bioactive Peptides as Potential Antihypertensive Agents (Chapter 16): Marine Medicinal Foods - Implications and Applications - Animals and Microbes; Advances in Food and Nutrition Research, 2012, 65: 249-260.

[262] Chatterjee M ; Role of Fish Oil from Gene Expression to Pharmacological Effect in Cancer Prevention : Nutrition, Diet and Cancer; 2012: 541 - 555.

[263] Nazlin KH and Chitundu K ; Bioactive Peptides and Proteins from Fish Muscle and Collagen (Chapter 14): Bioactive Proteins and Peptides as Functional Foods and Nutraceuticals, 2010: 203-223.

[264] Pádraigín A et al. ; Bioactive Proteins and Peptides from Macroalgae, Fish, Shellfish and Marine Processing Waste (Chapter 2): Marine Proteins and Peptides: Biological Activities and Applications, 2013: 5-39.

[265] Ulrike G et al. ; Bioactive compounds from marine mussels and their effects on human health; Food Chemistry, 2014, 142: 48-60.

[266] Keeton RW et al. ; Pharmacologic Food Reactions : Food Allergy: Adverse Reactions to Foods and Food Additives (Chapter 35). Blackwell Publishing Ltd. (4th Ed), 2008: 430-442.

[267] Chen JP et al. ; Effects of different drying treatments on the stability of carotenoids in Taiwanese mango (Mangifera indica L.). Food Chemistry, 2007, 100: 1005-1010.

[268] Le Marchand L ; Cancer preventive effects of flavonoids: A review. Biomedicine and Pharmacotherapy, 2002, 56: 296-301.

[269] Nijveldt RJ et al. ; Flavonoids: a review of probable mechanisms of action and potential applications. American Journal of Clinical Nutrition, 2001, 74: 418-425.

[270] Traka MH and Mithen RF ; Plant Science and Human Nutrition: Challenges in Assessing Health-Promoting Properties of Phytochemicals. The Plant Cell, 2011, 23: 2483-2497.

[271] Juana FL et al. ; Beneficial Health Effects of Bioactive Compounds Present in Spices and Aromatic Herbs: Studies in Natural Products Chemistry (Chapter 4). Elsevier B.V., 2012, 37: 115-134.

[272] Jae WS and Kevin CC ; Observational Studies: Cohort and Case-Control Studies. Plastic and Reconstructive Surgery, 2010, 126(6): 2234-2242.

[273] Colditz GA; Overview of the epidemiology methods and applications: strengths and limitations of observational study designs. Critical Reviews in Food Science and Nutrition. 2010, 50(Suppl 1): 10-12. 
[274] Castillo RC et al. ; Observational studies in the era of randomized trials: finding the balance. Journal of Bone and Joint Surgery., 2012, 94(Suppl 1): 112-117.

[275] Papadakis EN et al. ; Effect of the form of the sesame-based diet on the absorption of lignans. British Journal of Nutrition, 2008, 100: 1213-1219.

[276] Morisset AS et al. ; Impact of a lignan-rich diet on adiposity and insulin sensitivity in post-menopausal women. British Journal of Nutrition, 2009, 102: 195-200.

[277] Nurmi T et al. ; Dietary intake and urinary excretion of lignans in Finnish men. British Journal of Nutrition, 2010, 103: $677-685$.

[278] Mazur WM et al. ; Phyto-oestrogen content of berries, and plasma concentrations and urinary excretion of enterolactone after a single strawberry-meal in human subjects. British Journal of Nutrition, 2000, 83: 381-387.

[279] Heald CL et al. ; Phyto-oestrogens and risk of prostate cancer in Scottish men. British Journal of Nutrition, 2007, 98: 388-396.

[280] Seal CJ ; Whole grains and CVD risk. Proceedings of the Nutrition Society, 2006, 65: 24-34.

[281] Lærke HN et al. ; Quantitative aspects of the metabolism of lignans in pigs fed fibre-enriched rye and wheat bread. British Journal of Nutrition, 2009, 102: 985-994.

[282] Saarinen NM and ThompsonLU ; Prolonged administration of secoisolariciresinol diglycoside increases lignin excretion and alters lignan tissue distribution in adult male and female rats. British Journal of Nutrition, 2010, 104: 833-841.

[283] Adlercreutz H ; Lignans and human health. Critical Reviews in Clinical Laboratory Sciences, 2007, 44(5-6): 483-525.

[284] Reintjes R and Krumkamp R ; Methods of infectious disease epidemiology for public health services: case control studies as bridge between practical work, surveillance and epidemiology. Gesundheitswesen, 2005, 67(12): 840-844.

[285] Knol MJ et al. ; What do case-control studies estimate? Survey of methods and assumptions in published case-control research American Journal of Epidemiology. 2008, 168(9): 1073-1081.

[286] Lewallen S and Courtright P ; Epidemiology in Practice: Case-Control Studies. Community Eye Health. 1998, 11(28): $57-58$.

[287] Teicher BA ; Tumour models for efficacy determination. Molecular Cancer Therapeutics, 2006, 5: 2435-2443.
[288] Skalska M et al. ; Advantages and limitations of using Caco-2 cells for in vitro $\mathrm{M}$ cell model. Conference Publication, 2010, NA: $1 p$.

[289] Sandberg AS ; The Use of Caco-2 Cells to Estimate Fe Absorption in Humans - a Critical Appraisal. International Journal for Vitamin and Nutrition Research, 2010, 80(4-5): 307-313.

[290] Grajek W and Olejnik A ; Epithelial cell cultures in vitro as a model to study functional properties of food. Polish Journal Of Food And Nutrition Sciences, 2004, 13/54(SI 1): 5-24.

[291] Larrick et al. ; gamma-Tocopherol therapy for Restenosis Prevention. Patent Application Publication. United States, $2013: 13 p$.

[292] Brigelius-Flohé R ; Bioactivity of vitamin E. Nutrition Research Reviews, 2006, 19(2): 174-186.

[293] Jucker M ; The benefits and limitations of animal models for translational research in neurodegenerative diseases. Nature Medicine, 2010, 16: 1210-1214.

[294] Loisel S et al. ; Relevance, advantages and limitations of animal models used in the development of monoclonal antibodies for cancer treatment. Critical Reviews in Oncology/Hematology, 2007, 62(1): 34-42.

[295] Srinivasan K \& Ramarao P ; Animal models in type 2 diabetes research: An Overview. Indian Journal of Medical Research, 2007, 125: 451-472.

[296] Holmes AM et al. ; Animal models of asthma: value, limitations and opportunities for alternative approaches. Drug Discovery Today, 2011, 16(15/16): 659-670.

[297] Morgan SJ et al. ; Use of Animal Models of Human Disease for Nonclinical Safety Assessment of Novel Pharmaceuticals. Toxicologic Pathology, 2012, 00(0): 1-11.

[298] Anonymous; La santé vient en mangeant : le guide alimentaire pour tous. Programme national nutrition-santé (PNNS): 2002 : $130 \mathrm{p}$.

[299] Zvaigzne G. and Kārklina D ; Health Promoting Chemical Components of Orange Juice. Proceedings of the Latvian Academy of Sciences (Section B), 2013, 67(4-5): 329-333.

[300] Lampe JW ; Health effects of vegetables and fruit: assessing mechanisms of action in human experimental studies. The American Journal of Clinical Nutrition, 1999, 3(70): 475S-90S. 